\title{
高分子絶縁フィルムの破壊遅れ時間之 その温度特性
}

$\begin{array}{llll}\text { 愛媛大学 } & \text { 公 } & \text { 勇 } \\ \text { 愛媛大学 有 井 清 盖 }\end{array}$

\section{1. まえがき}

固体絶縁物の破壊機構についての研究は，乙れまで 数多くなされてきているが，その本質的な破坡機棤に ていては十分には知られていない。特得分子のよう な非晶質物質汇就いては，高電界中比ける電荷坦体 の物理的ふるまい（寿命, 移動度など）について未知 な点が多い。筆者らは，固体絶縁物の本質的破境機構 を知るために，気体放電の研究によく用いられる破罗

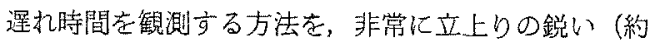
1ns）パルサーを用いて試みた。とれまで室温におい てポリエチレン $(\mathrm{PE})$, ポリエチレンテレフタレート (PET)。ポリカーボネイト (PC) の三種の高分子と, 分子性結晶であるマイカ (Muscovite Mica, Phlogopite Mica) 用いて測定を試み，一匛の成果を修め た (1)。次に，上り物性的な意味を知るためには，測定 温度を大きく変光ること方有效であると考元，77 Kの 低温加 $373 \mathrm{~K}$ の高温に至るまでの広籍囲な温度領域 で，高密度ポリエチレンを中心に测定試みた。

固体絶縁物の破塄強度の温度特性は, アルカリ八ラ イドのようなイオン結晶では， $\partial F_{B} / \partial T>0\left(F_{B}\right.$ ：絶縁

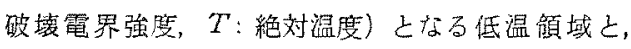
$\partial F_{B} / \partial T<0$ 之なる高温頒域とに分けて若えられてい る。その定性的理解は，低温においては電極より注入 された電子は，固体内での移動が容易で，電界により 加速されやすく，高速電子となる。その高速䉓子か源

Breakdown Time-Lags and Their Temperature Characteristics of Polymer. By I. KITANI, Member \& K. ARI, Member (Department of Electrical Engineering, Faculty of Engineering Ehime Universiy).

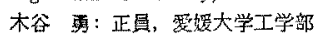

有井清往：正圆，唒復大学工学部

\begin{tabular}{|l|}
\hline 論 文 \\
\hline $49-A 35$ \\
\hline
\end{tabular}

子よの衝突において新たな電子偟みだし，電子なだ れと発展して破壊に尊加机ると考えら机ている。温度 上昇上ともにフォノンとの衝突の確率加增し，平均自 由行程が短くなり，䉓照より得られるエネルギーが小 さくなり，原子との衝突化和いて新たな雷子を産みだ すととが困難上なる。したがって，電子なだれが起と りにくくなり，温度上昇ととも破壊强度が上がると 考えら机ている。さらに高温炕ると，Frölich 氏(2) の論ずるところによれば，伝導帯中での電子数が増大

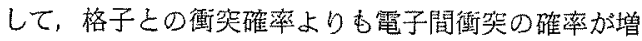
し, 多数の熱電子の拹合作用に上り固体が不安定状態 となり破㙲に導び加れるとしている。

高分子についても，多くの理類について絶縁破買強 度の温度特性が測定されているが，その多くはガラス 転移点古るいは軟化点など，弹性率が低下する温度点 で急激に䋓縁破塄強度が低下する例が多い(3)。宮入氏 ら(4)がパイレンなどを添加したボリエチレンと無添加 ポリエチレンを比校しつつ，直流扔よびインパルスで の破壤電界強度の温度特性を求めている。三机上れ ば，無添加ポリエチレンのインパルス破坡は約 $200 \mathrm{~K}$

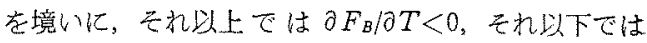
わずか化 $\partial F_{\partial} / \partial T>0$ となっている。

䈇者らの得た結果においても，後述するラウエプロ

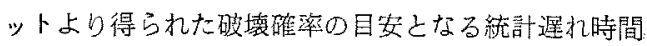

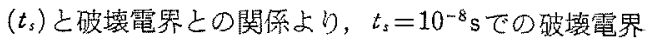
強度を求め，乙の温度特性を得たが，宮入氏らが得た 結果之同様の結果であった。

すで報告 ${ }^{(1)}$ したとおり PETゃPCでは，室温に

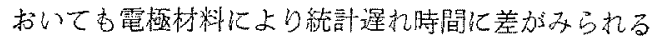
のに対して，PEではその効果を得るととができなか った。ところが，PE に频いても170K 以下の低温て 
は電極材料効果が見いだされた。

破㯖に要する最小時間である形成㺚れ時間について は, シンクロスコープを $100 \mathrm{MHz}$ 加ら $500 \mathrm{MHz}$ 亿変 えて，眭間分解能が向上したのて，より詳しく榆討し た。高密度PEに斿いては，77Kて，测定電界強度 ではいずれも500ps以下であった。298Kにおいては $6.4 \mathrm{MV} / \mathrm{cm}$ で約 $1 \mathrm{~ns}, 373 \mathrm{~K}$ では $4.6 \sim 5.0 \mathrm{MV} / \mathrm{cm}$ で約 Insであった。

\section{2. 実験方法}

用いたパルサーはててれまて報告してきたと同様(1) に Fletcher 丘の開発(1)(5) した商氮压スイッチ（三点

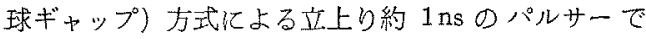
ある。

用いた試料は高密度 PEスミカセンハード(厚さ 18 $\pm 1 \mu$ 扰よび $28 \pm 1 \mu$ )とPET(厚さ $24 \pm 1 \mu$ )である。 これらの試料に AuあるいはAIを真空蒸着した点な と，電極搆成す前回上同様(1である。

温度制期は， $77 \mathrm{~K}$ は液体烓素中で測定し，170Kは シリコーン油中に試料を組み入れたセルを液体窒素中

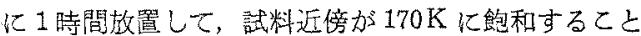
をあらかじめ熱電対に上り確かわたうえで行なった。 215K は試为パラフィンでモールドしたものをドラ イアイスとメチルアルコール混合体中で放置したのち 測定を行なった。高温部は熱制御しえる恒温油槽中に 試料を組み入れた七ルを放置して，試料近傍が指定温 度になっていることを水銀温度計で確認したのち测定 を行なった。

同一試料と見なしえる 20〜25 個の試料に対して同

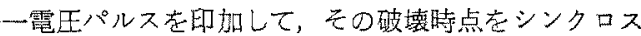
コープ (Tektronix-7904，500MHz）で钼測した。時

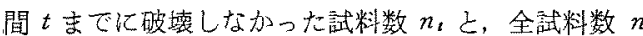
との比 $n_{t} / n$ を緥軸に対数目盛てとり，横朝に時間 $t$ をとる，いわ沙るラウエプロットを行ない整理した。 気体放電のような電子なだ机による破睓では，次のよ うな関係が成立するととはよく知られている。

$$
\frac{n_{t}}{n}=\exp \left(-\frac{t-t_{F}}{t_{s}}\right)
$$

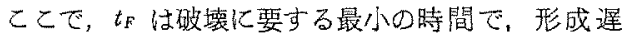
れ時間乙呼ばれ， $t$ s は統詐遲れ時間で，破壊遅れの ばらつきの度合いを表わす。この関係は $\log n: / n$ と時 間 $t$ 関係，すおわらうウエプロットが直線となるこ とを示している。㦈化カりウム $(\mathrm{KCl})$ 扰よびイオウ $(\mathrm{S})$ のような結晶体に颅いても，この閔係が成立するとと は，犬石氏ら ${ }^{(6)}$ はる赛験で得られている。高分子に おいては，筆者らが室温においてパルス扐加後，比較
的時聞释過の少ない時点までは，直線性の良い結果が 得られることをすでに報告(1してる。

今回の報告では，温度範囲を広く取ったため，直線 性が失なわれる可能性考考慮して，縄計遅れ時間を単 なる破壊强度の目安之考えて，得られたラウエプロッ トの全時間領域 $(0 \sim 100 \mathrm{~ns})$ を含め，最小二乗法で近

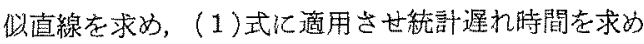
た。

形成暒れ時間 $t_{F}$ については，前回の埌告ではラウ エプロットにより得られた㨁線が $n t / n=100 \%$ の朝 切る時点を $t_{F}$ としたが， $t_{F}$ の絶対量肪小さいため 誤差が大きく，加再圐性に元しいため，今回は同一

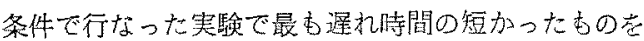
北成晕九特間 $t_{F}$ として採用した。

\section{3. 実験結果と検討}

〈3.1〉統計遲れ時間上温度特性高密度 PE(18 片または28）のラウェプロットを例として第1淄〜 第 3 图に示した。第1㘡は170Kの結果，第 2 图，第 3図はそれぞれ $298 \mathrm{~K} ， 373 \mathrm{~K}$ の結果である。しれら

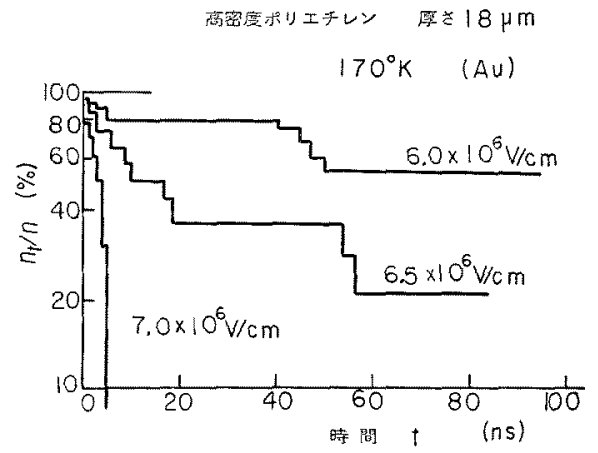

符 1 図 ラウエプロット図

Fig. 1. Laue polt.

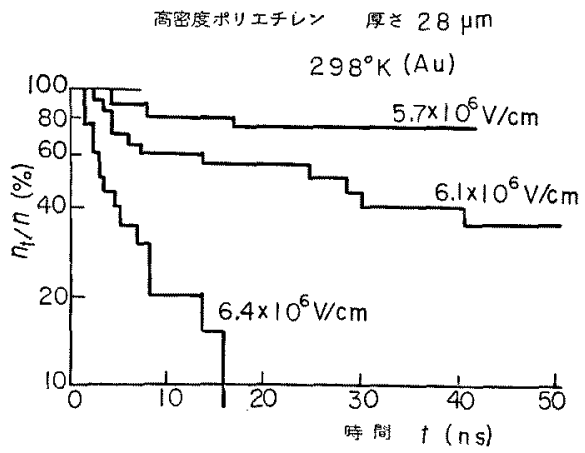

第 2 图 ラウエプロット図

Fig. 2. Latue plot. 


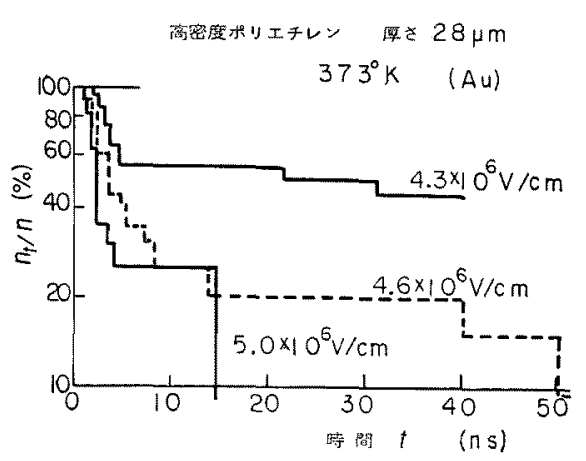

第3図ラウエプロット図

Fig. 3. Laue plot.

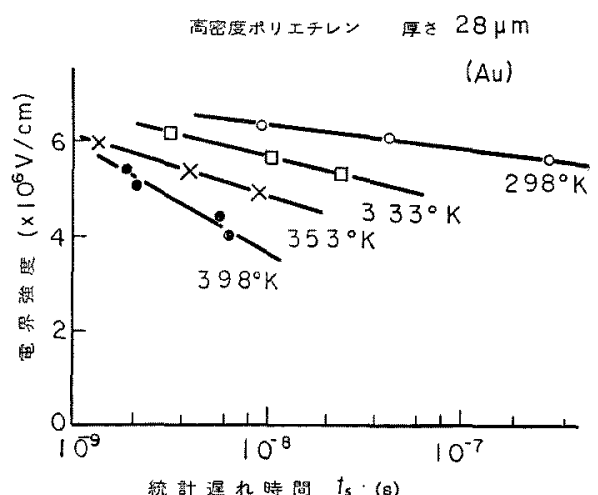

第 4 図統計浑れ時間之破垻強度之の関係

Fig. 4. Plot of the breakdown strength against the statistical time-lags.

のラウエプロットより，前章で述へたようにして統計 幄机時間 $t_{s}$ 老求めた。得られた $t_{s}$ 之電界强度之の関 係を，高温部について第4図に例として示した。との 図より，同一条件においては電界強度が高くなるにつ れて統計抙机時間 $t$ 、は小さくなっている。統計䐅れ 時間が小さいことは破塄確率が高いことであり，当然 の結果である。また室温以上では，同一電界强度に対 して温度上昇上ともに統計遅れ時間が小さくなってい るととがわかる。したがって，温度上昇とと屯に破壊 電界強度が下がることがわかる。

第 4 図で示されるような電界強度と統計遅れ時間の 関係加ら，統計遅九時間 $t_{s}=10^{-8} \mathrm{~s}$ となる電界強度を 求め，その温度特性を高密度 PEについて示せば第 5 図の上うになる。乙の電界強度は, 形成遅れ時間 $t_{F}$ を無視して，幅 $10^{-8} \mathrm{~S}$ の単一パルスによる破壊の実験 を行なえば，乙の電界強度に捺いては平均として 63.1 \%の試料が破壊することを意味する。

この図より $t_{\mathrm{s}}=10^{-8} \mathrm{~S}$ となる破壊電界強度は $170 \mathrm{~K}$

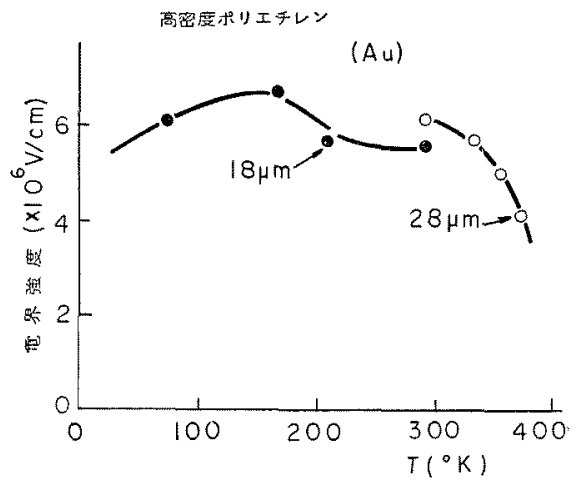

第 5 図 統計遅れ時間 $t:=10^{-8} \mathrm{~s}$ と扔ける 破壊强度の温度做存性

Fig. 5. The temperature dependence of the breakdown strength at the statistical timelags $t_{s}=10^{-8} \mathrm{~s}$.

以下で $\partial F_{B} / \partial T>0$ ，そ机以上で $\partial F_{B} / \partial T \leqq 0$ となるこ とがわかる。この結果は，宮入氏ら (4)が無添加ポリエ チレンについて行なったインパルス破壊の結果と類似 のものである。ただし第 5 図で示される結果は，室温 以上では試料厚さが $28 \mu$, 室温以下では $18 \mu$ で実験さ れている。室温沈いて，18 が $28 \mu$ で結果より破壊電界強度が低くなっている。 この原因は，試料の表面あらさが陚料の厚さにかかか らず一定であるため，試料の厚さが小さい $18 \mu の$ 試料 のほうが表面あらさの占める割合が大きく，実質的な 電界强度は $28 \mu$ の試料の場合上り大きくなっている ためと考えた。しかし，表面あらさの数值走知ること ができないので細かい諭議をすることはできない。

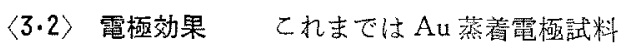
のみの結果を述へててきが，蒸着電極を Au から Al に変えて得た結果と比較して述べる。すでに報告した 室温での結果において, PET および PCではAu電極 試料よりA1電極試料のほうが破堎しやすいのに対し， PE では電極材料の差による結果の違いはみられない ことが明らかにさ机ている。しかし，PEに拉いても $170 \mathrm{~K}$ 古るいは $77 \mathrm{~K}$ の低温に扔いては，笔極効果が 存在することが見いだされた。

第 6 図に $170 \mathrm{~K}$ および $298 \mathrm{~K}$ 亿戈㚈る Au電極試 料と $\mathrm{Al}$ 電極試料伅ついて筺界強度上統計㩧机時間 との関倸を示した。ての図より，室温 (298K)では電 極材料汇上って特性の差はみら机ないが，170K では 明らか儿 Al 電極のほうが同一電界強度に対して統計 荤れ時間が小さく，したがって，破坡しやすいととが 示さ㧈てる。また第7四において, $77 \mathrm{~K}$ においてあ 電極效果が存在することを示した。しかし $215 \mathrm{~K}$ 以上. 


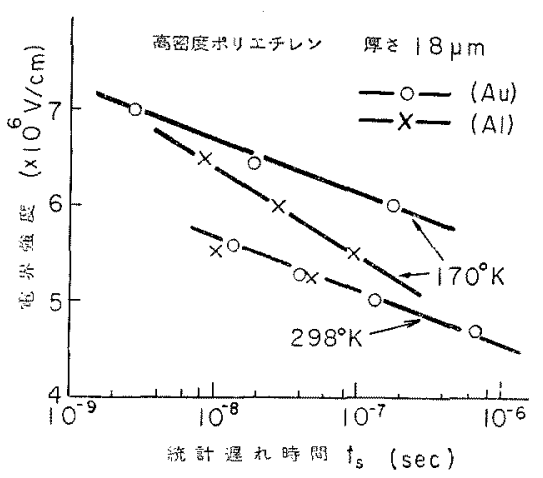

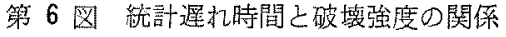

Fig. 6. Plot of the breakdow strength against the statistical time-lags (the electrode effect).

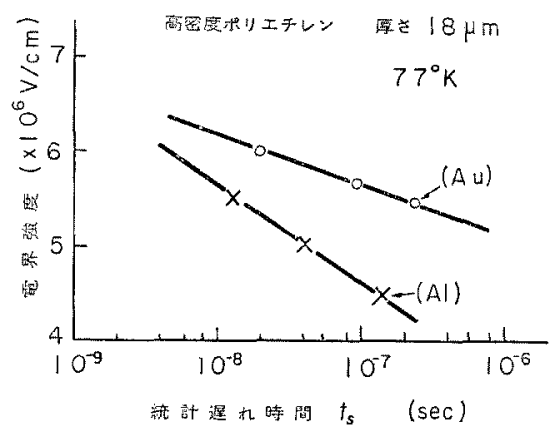

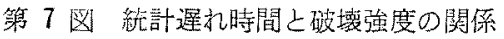

Fig. 7. Plot of the breakdown strength against the statistical time-lags (the electrode effect).

の温度では，いずれす室温と同様に電極効果がないこ とが判明している。

PET では室温に扮いて電極效果が存在するが，373 Kの高温では己の效果加消失する。第 8 図に，ての結 果安統計遌机時間と電界強度の関后より示した。

これらの結果にみられる電極効果, すなわち，霓極 材料に上万統計迤れ時間の差は，Au 0 仕㚜関数 ( $\Phi_{\mathrm{Au}}$

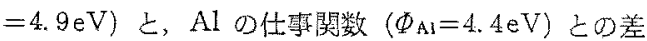
によるるの上考えられる。単一電子なだれによる破壤 の場合は，統計遅れ時間ば次式で与えられる ${ }^{(6)(7)}$ 。

$$
t_{s}=1 / \nu_{0} \exp \left\{N_{c} / \exp (\alpha L)\right\}
$$

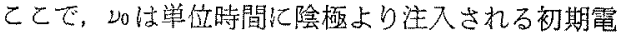

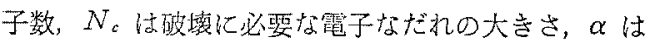
衝突電雄係数，Lは霄子なだれが $N_{c}$ 個に成長する距 離である。

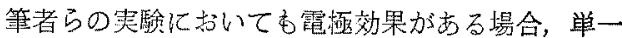
電子なだ机之考え，(2)式汃旗用しえるなら济初期電

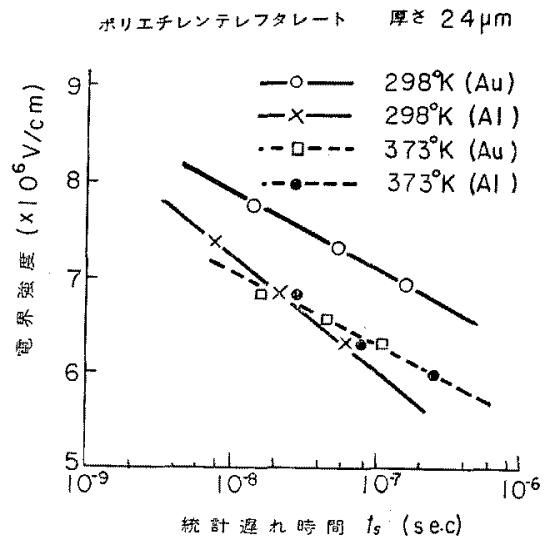

第 8 図 統計痋れ時間之破淁強度の関係

Fig. 8. Plot of the breakdown strength against the statistical time-lags (the electrode effect).

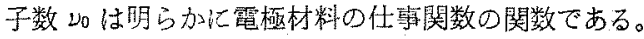
電㥛より電子加注入される機權は，ショットキ一效果

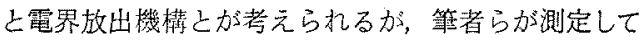
いるような高觜鼠では電界放出機權が支配的であるこ とばすすで報告したとおりである。

電界放出機構による注入電子数は，次式で与えられ $3^{(8)}$ 。

$\nu_{0}=\frac{2.2 e^{2} F^{2}}{8 \pi h \Phi} \exp \left(-\frac{3 \pi V \overline{2 m \Phi^{3}}}{2.96 h e F}\right) \ldots \ldots$

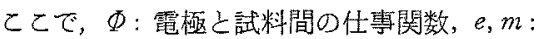

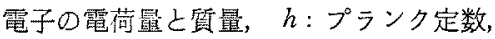

$F$ : 電界強度。

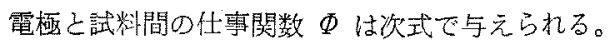

$$
\Phi=\Phi_{m}-\chi_{i}
$$

ここで， $\Phi_{m}$ : 電極金属の仕事関数， $\chi_{i}$ : 部料 の電子㯒和度

いま PETの霄子親和度を $2.0 \mathrm{eV}$ とすると ${ }^{(9)}, \mathrm{Au}$ 電極の場合 $\Phi_{\mathrm{Au}}=4.9 \mathrm{eV}$ であるから，(4) 式により $\Phi$ は $2.9 \mathrm{eV}, \mathrm{Al}$ 電極の場合は $2.4 \mathrm{eV}$ となる。電界強 度 $F$ を $8 \times 10^{6} \mathrm{~V} / \mathrm{cm}$ として，(3)式を用いて $\mathrm{Al}$ 管 極の場合に注入される行期電子数 Do(A.1) 之，Au電極 の場合に注入される初期電子数 $\nu_{0}(\mathrm{Au})<0$ 比, $\nu_{0}(\mathrm{~A}) /$ עo(Au) 在求めると $4.0 \times 10^{4}$ となり，A1 電極加的注 入される電子数のはうがるかに多い。笔極より注入 される電子が破滾に奇与する電子なだれ破堎であれ ば，統計漣れ時間 $t_{s}$ は電極材料の壮事関数の影響艺

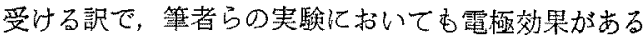
場合，電子なだれによる破壊であると考えている。

PE の $215 \mathrm{~K}$ 以上での温度における結果，あるいは PET の 373K の結果のようK, 電極效果加存在しな 
い場合についてあ考察してみる。PE のような高分子 の高笔界電気伝導は, Poole-Frenkel 効果により試料 内部より放出された電子によるもの上されている。

$\mathrm{PE}$ の場合, 田中氏ら ${ }^{(10)}$ 亿上机伝導帯の下 $2 \mathrm{eV}$ のととろにあるドナー準位から放出されれた電子が，木 ッピングしながら移動しているとしている。とてろで 䈉者らが測定しているような短時間で破壊化至るよう 极著しい高電界の場合は，内部上り放出される電子数 あ非常に多い上考えることができる。試料内部より電 子が放出される確率は，温度上昇と之香化指数関数的 に增加するので，ある温度以上では電極より注入され る電子数上り試料内部加ら放出さ机る電子数のほうが 多くなり，試料内部加ら倣出される電子のほうが破壊 化寄与する可能性が大きくなると考元られる。高泌度 $\mathrm{PE}$ の場合 $170 \mathrm{~K}$ 以下では電極効果がみられ，215 K 以上ではその効果がみられず，また PETの場合， 室温 $(298 \mathrm{~K})$ では電極效杲が存在したのに対して，373 $\mathrm{K}$ の高温ではその効果が消失した結果は，初期電子の 由来の違いによるものであると考えるれる。また，乙

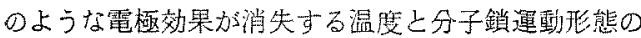
变化する温度 $T_{\text {。 }}(\mathrm{PE}$ て $230 \mathrm{~K}, \mathrm{PET}$ で $370 \mathrm{~K})$ 加比

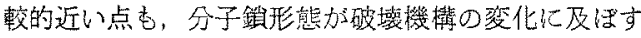
可能性があると思われる。

第 5 図に书いて，電極效果放消失する $215 \mathrm{~K}$ 以上の 温度では， $\partial F_{B} / \hat{\partial} T \leqq 0$ となっている事実は，PE 試料 内部上り放出される電子数の增加によると考えられ る。これらの理由加ら，電極効果のない領域に括いて も初期電子加誈料内部市ら放出される点で，電極效果 加ある低温での領域と異なるが，電子なだ机的破壊之 考えて不つごうはない。また，得られたうウエプロッ トが電極乵果のない領域であ，近似的に(1)式の関媇 を満たしている点卆，電子なだれ的破壊であることを 示唆している。

ここで，他の破填機構による可能性について検討し てみる。純熱破壞の可能性化ついては，篗者方分測定

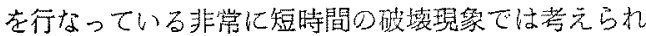
ないてとはすでに報告した。Frölich 氏(2)の諭じてい る熱電子破壊においても，nsの上うな短時間での破 壊は考元難く，もし，その上うな短時間での破㙏が起 こりえても，之の過渡的現象は諭じられて扔らず，ま た同一条件において $1 \mathrm{~ns}$ で破壊する場合すあれば，

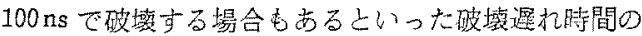
ばらつき，すなわち(1)式を淗たしうるととは説明が 困難である。

〈3・3〉形成遅れ時間と移動度前章で述へたと おり，今回の報告では形成渥れ時闘は同一条件に晾い
て行なった測定で最も遮れ時間の短かったものを形成 㺚れ時間として採用した。

$77 \mathrm{~K}$ での PE の形成遅机時間は著しく小さく，500 ps 以下であるため，筆者らの測定能力の範团外であ る。室温 (298K)では $6.4 \times 10^{6} \mathrm{~V} / \mathrm{cm}$ に求いて, $373 \mathrm{~K}$ では 4.6 5.0 $0 \times 10^{6} \mathrm{~V} / \mathrm{cm}$ に括いて形成漣机時間 $t_{F}=$ 1ns 索得た。得られた形成遅机時間加ら，なだれ破壊 における理論加ら得ら机る次式を用いて移度動を求め 第1婊にまさめた。

$$
\mu=d / F t_{F}
$$

ここで， $\mu$ : 移㖶陵， $d:$ 試料厚さ

第 1 表に上机ば， $298 \mathrm{~K}, 5.7 \times 10^{6} \mathrm{~V} / \mathrm{cm}$ のとき最小 值 $0.12 \mathrm{~cm}^{2} / \mathrm{s} \cdot V$ であり，他の場合いずれもそれ贝上で

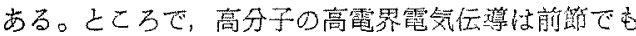

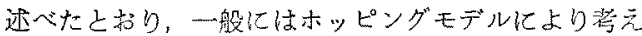
られている。し加し，ての理諭的性質加ら考元て，て の移動度は $10^{-2} \mathrm{~cm}^{2} / \mathrm{s} ・ V$ 以下であるとされている(11)。

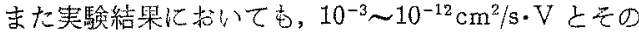
理諭茬裏づけている(12)ー(14)。しかるに，筆者らの得た 矽動度ははるかに大きく，むしろ結晶体仁通用される バンドモデルにより得られる值に近いものである。し かし，此較的結晶性が良いとさ机ているPEに执いて あ結晶の乱机は大きく，バンドモデルを単純に適用す ることはできない。高電界中でのキャリアの移動がホ ッピングモデルによるものであるよす机恬，篟者らの

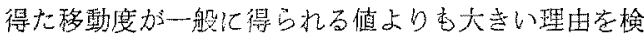
討して々よう。

ホッピングモデル代よる移動度が小ざくなる原因 は，古る状態電子がトラップされる期間に大きく支 配されているためである。見かけ上の移陲度牒は，

真の移動度 $\mu_{b}$ 上次の上うな関係を持つ。

$$
\begin{aligned}
& \mu_{a}=\mu_{b} \exp \left(-E_{T} / K T\right) \ldots \ldots \ldots \ldots \ldots(6) \\
& \text { こてで, } E_{T}: \text { トラップの深さ，K：ボルッ } \\
& \text { マン定数 }
\end{aligned}
$$

\begin{tabular}{|c|c|c|c|c|}
\hline 原 き & 瀑宽 & 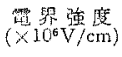 & 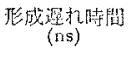 & $\left(\mathrm{cm}^{2} / \mathrm{s} \cdot \mathrm{V}\right)$ \\
\hline $18 \mu \mathrm{m}$ & $77 \mathrm{~K}$ & $5.5 \sim 6.0$ & $0.5 \mathrm{DT}$ & - \\
\hline \multirow{6}{*}{$28_{1 \mathrm{~m}}$} & \multirow{3}{*}{$298 \mathrm{~K}$} & 5.7 & 4 & 0.12 \\
\hline & & 6.0 & 2.5 & 0.18 \\
\hline & & 6.4 & 1 & 0.44 \\
\hline & \multirow{3}{*}{$373 \mathrm{~K}$} & 4. 3 & 2 & 0.33 \\
\hline & & 4.6 & 1 & 0.61 \\
\hline & & 5.0 & 1 & 0.56 \\
\hline
\end{tabular}

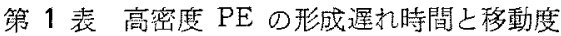

Table 1. The formative time-lags and mobility in high density polysthylene. 
真の移動度 $\mu_{0}$ はトラップから励起されたキャりア が伍導带中走走るときの移動度と考えている。宫た， 指数関数の項ばキりア（電子）がトラップから佰導 帯へ励起される確率考表わしている。トラップの深さ $E_{T}$ は高電界中厄畒 Poole-Frenkel 効果により，見加 け上，次式の上うに小さくなる(15)。

$$
\begin{aligned}
& E_{T^{\prime}}=E_{T}-\left(\frac{e^{3} F}{\pi \epsilon}\right)^{1 / 2} \ldots \ldots \ldots \ldots \ldots \ldots \ldots( \\
& \text { ここで, } E_{T}{ }^{\prime} \cdot \text { 見加け上のトラップの墚さ， } \\
& F: \text { 電界強度， } \varepsilon: \text { 誘電率 }
\end{aligned}
$$

特に篚者らの测定しているような著しい高電界では

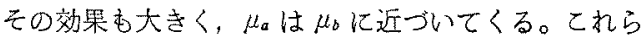
のこしはあくまで統計的な問題であり，個々の電子に 著目す机は長期間トラップされた状態にある電子もあ れば，伝導带中を長い距離の間トラップされることな く走る電子毛存在しうると考元られる。筆者ら加湘定 しているような非常に短い時間で破壊せしめるような 高笔界では，そのような高いエネルギーを持つ高速電 子の存在する確率高高く，乙の上うな高速電子加他原 子との衝乫において新たな篦子を座みだし，笔子なだ れ墱展し，破㳖現象のような非線形兒象が起こる己 考えられる。したがって，筆者らの得た移動度はホッ ピングしたり，トラップされたりしてさまざまな速度 で走る電子の中で，伝導带の上うな状態密度の高いエ ネルギー状態を，他原子との衝突で新たな電子を産る だしうるような高速で走る電子のみの移動度を検出し ていると考えられる。よって，バンドモデルにより得 られる移動度に近い倪を持ち得る。

また，笥者らの得た移動度が大きい他の理由として は，電極效果のない領域では試料的部より放出される 霓子が䉓子なだれの初期電子となることが多いため， いくつかの電子なだれが協力して破壊に゙導く可能性が ある。との場合，(5)式に抢方試料の厚さ红形成さ

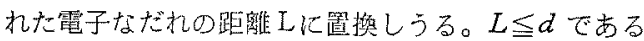
ため得られる移動疼は第1表に示した值よりも小さく

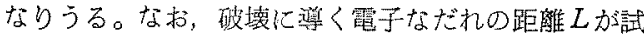
料の厚さdより小さい之圆さ效果加存在しないと考元 られるが，室温での結果で厚さ效果を得るこよができ なかったことはすで報告(1)していると扔りである。 第1表に抋いて $298 \mathrm{~K}$ 执よび $373 \mathrm{~K}$ のような電極効 果のない領域で，電界強度が大きくなるにつれて得ら れた移動度が大きくなるのも上で述心゙たような理由に よるとするとすれば，さらに高電界では形成遲れ時闆 は指数関数的に城少し，さらに测定が困離になるであ 万う。

電極効果がある頜域においては，電子なだれの初期
電子は笔極より注入される電子であるため，(5)式は そのまま適用できるにすかか⿰力口すす，得られた移動度 は電極効果のない領域より李さらに大きい。これは電 極より注入された電子は，低温では熱散乱される確率 が少なく，移動が容易で，長い距㸌を走り，トラップ されるまで衝乫電離を起こし，電子なだれを形成す るためであると考えられる。このととは，電極交果の ある領域に执いて，170Kよりより低温の $77 \mathrm{~K}$ のほ うが破壊電界強度が小さい事実からあ裹づけられる。

\section{4. まと め}

內上の奏験結果之㛟討から次の結諭が得られる。

（1）高密度 PE の破顶機棒は，170K 以下の低温 では主に電極より注入された電子を初期電子とする電 子なだれ破罗であり， $215 \mathrm{~K}$ 以上の高温では，試料内 部加ら主に放出された電子によるいくつかの電子なた れの咕合で破壊する。PET では $298 \mathrm{~K}$ において電極 より注入された電子による電子なだ机破壊， $373 \mathrm{~K} に$ 㧍いては試料内部より放出されれた電子によるなだれ破 罗である。

（2）高密度 PE の形成痋机時間は，77K に掠い ては $500 \mathrm{ps}$ 以下, $298 \mathrm{~K}$ では $6.4 \times 10^{6} \mathrm{~V} / \mathrm{cm}$ におい て約 $1 \mathrm{~ns}, 373 \mathrm{~K}$ では 4.6〜 $5.0 \times 10^{6} \mathrm{~V} / \mathrm{cm}$ に极いて 約 Insである。PET では，いずれの条件においてい 500 ps である。

（3）得られた形成途れ時間から，単一電子なだれ 譏構と仮定して 高密度 PEの移勤度を求めると, $77 \mathrm{~K}$ に和いては $0.6 \mathrm{~cm}^{2} / \mathrm{s} \cdot V$ 以上, $298 \mathrm{~K}$ では $0.12 \mathrm{~cm}^{2} /$ $\mathrm{s} \cdot \mathrm{V}$ 以上, $373 \mathrm{~K}$ では $0.33 \mathrm{~cm}^{2} / \mathrm{s} \cdot \mathrm{V}$ 以上でする。 (昭租 48 年 7 月14日受付，同 48 年 12 月 11 日再受付)

\section{文献}

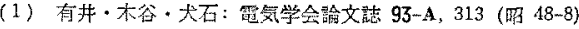

(2) H. Froblich: Proc. Roy. Soc. A 188, 521 (1947)

(3) L. DL. Ball: Proc. Instn Elect. Engrs 98, I, 84 (1951)

(4) 宮入, 他: 電学綕 91, 1962 (昭 46-10)

(5) R.C. Fletcher: Rev. Sci. Instrum. 20, 861 (1949)

(6) 犬石・吹田：雷学誈 74，150（昭 29-1)

(7) Y. Inuishi \& T. Suita: J. Phys. Soc. Japan 7, 640(1952)

(8) J.G. Simmons: J. Appl. Phys. 34, 1793 (1963)

(9) A.C. Lilly, et al, ; J. Appl. Phys. 41, 2007 (1970)

(10) 田中・犬石: 電学誌 89,693 (昭 44-4)

(11) 由中: 電気学会總緑材料资料 IM-7-38 (昭 47)

(12) D. K. Davies: J. Phys. 5-D (1972)

(13) E.H. Martin, et al.: J. Non-Cvyst Solid 4, 133, (1970)

(14) M. Ieda, et al. : Japan J. Appl. Phys. 9, (1970)

(15) D. R. Lamb: "Electricl Conductiom Mechanisum in Thin Insulating Film" (1967) Methuen. and Co. Itd., Lodon
} 